\title{
Raka Riki sebagai Ujung Tombak Strategi Komunikasi Pariwisata Dinas Kebudayaan dan Pariwisata Provinsi Jawa Timur
}

\author{
Helmi Kurniawan1, Redi Panuju*2 \\ Pascasarjana Ilmu Komunikasi Universitas Dr. Soetomo Surabaya, Indonesia1,2 \\ Email: redipanuju@gmail.com
}

\begin{abstract}
This study aims to determine the communication strategy of the Culture and Tourism Office of East Java Province in utilizing the East Java Raka Raki. The communication strategy analysis by Berlo's SMCR theory (1960) and on the strategic communications approach. Data collection techniques in this research were carried out using field studies (interviews). The research findings show that the formulation of the communication strategy has fulfilled the vision and mission, opportunities and strengths, as well as fulfilling the long-term goals in making use of the East Java Raka Raki. This is supported by the implementation of a communication strategy for the Tourism Industry Sector of East Java Disbudpar with the support of IRARI which is a legal entity. Evaluation of communication strategies in carrying out East Java Raka Raki activities /programs is based on unplanned or unscheduled meetings, meetings are held once every 3 (three) months.
\end{abstract}

Keywords: Communication Strategy, Berlo SMCR theory, Tourism Ambassador.

\begin{abstract}
Abstrak
Penelitian ini bertujuan untuk mengetahui strategi komunikasi Disbudpar Jatim dalam mendayagunakan Raka Raki Jatim. Analisis strategi komunikasi ditunjang dari teori SMCR Berlo (1960) dan pada pendekatan strategic communications. Teknik pengumpulan data dalam penelitian ini diakukan dengan menggunakan studi lapangan (wawancara). Temuan penelitian menunjukkan bahwa perumusan strategi komunikasi telah memenuhi visi dan misi, peluang dan kekuatan, serta memenuhi tujuan jangka panjang dalam mendayagunakan Raka Raki Jawa Timur. Hal ini ditunjang dengan implementasi strategi komunikasi Bidang Industri Pariwisata Disbudpar Jatim dengan dukungan IRARI yang berbadan hukum. Evaluasi strategi komunikasi dalam menjalankan kegiatan/program Raka Raki Jawa Timur didasarkan atas rapat tidak terencana atau tidak terjadwal, rapat dilakukan 3 (tiga) bulan sekali.
\end{abstract}

Kata Kunci: Strategi Komunikasi, teori SMCR Berlo, Duta Wisata.

\section{A. PENDAHULUAN}

Komunikasi pariwisata setidaknya mengandung dua perspektif, yakni dari segi proses komunikasi merupakan kegiatan upaya menyebar luaskan informasi tentang semua hal yang berhubungan dengan industry pariwisata, baik tentang lokasi destinasi wisata, transportasi dan akomodasi, keunggulan, keunikan, maupun hal-hal yang berkaitan dengan logistic yang harus disiapkan oleh wisatawan. Juga tentang media yang digunakan untuk menyebar luaskan informasi, mulai dari media arus utama sampai media siber (Panuju, 2018: 187-194). Sedangkan dari sudut pandang Komunikasi Pemasaran (Panuju, 2019:169-176) cenderung berisi komunikasi pemasaran social. Komunikasi pemasaran social jauh lebih pelik ketimbang komunikasi pemasaran produk, sebab menyangkut kepercayaan (trust) khalayak terhadap isi informasi.

\footnotetext{
* Corresponding author 
Upaya pengembangan kepariwisataan mempunyai peranan penting untuk memperluas dan memeratakan kesempatan berusaha, memperbesar pendapatan nasional, mendorong pembangunan daerah dalam rangka meningkatkan kesejahteraan dan kemakmuran rakyat serta memupuk rasa cinta tanah air. Pengembangan sektor pariwisata yang dilakukan dengan baik akan mampu menarik wisatawan domestik maupun wisatawan asing. Sektor pariwisata merupakan salah satu penunjang majunya suatu wilayah, terutama di pada wilayah yang sudah diberikan wewenang atas otonomi daerahnya. Desentralisasi merupakan suatu kondisi yang tentunya tidak perlu lagi ditakutkan oleh masyarakatmasyarakat daerah. Hal ini karena masyarakat daerah memiliki modal yang dapat diandalkan untuk kemajuan daerahnya, salah satunya di bidang pariwisata. Jawa Timur merupakan provinsi besar dengan luas $\pm 48.000 \mathrm{~km} 2$ yang memiliki beragam destinasi wisata yakni potensi alam yang kurang lebih sebanyak 772 destinasi, beberapa destinasi ini diantaranya Taman Nasional Bromo Tengger Semeru (TNBTS), Taman Nasional Meru Betiri, Taman Nasional Baluran dan Alas Purwo. Beberapa pariwisata tersebut berada di bawah naungan Dinas Kebudayaan dan Pariwisata Provinsi Jawa Timur.

Pemerintah Jatim melalui Dinas Kebudayaan dan Pariwisata Provinsi Jawa Timur telah melakukan berbagai macam upaya untuk meningkatkan fasilitas wisata dan promosi agar dapat menarik minat wisatawan agar dating berwisata ke Jawa Timur. Guna menjaring dan mendayagunakan generasi muda yang memiliki potensi, dalam menjalankan strategi komunikasi, Dinas Kebudayaan dan Pariwisata Provinsi Jawa Timur mengadakan pemilihan Raka Raki (Duta Wisata) JawaTimur. Raka Raki (Duta Wisata) adalah sebuah sebutan yang akrab sekaligus masih asing di sebagian kalangan masyarakat, yaitu sebagai ikon pariwisata dan kebudayaan yang terdiri dari sepasang remaja putra dan putri yang terpilih setelah melewati serangkaian seleksi dengan landasan 5B (Beauty, Behaviour \& Brain, Brave and Believe). Pada prosesnya banyak orang yang belum mengetahui siapa dan apa saja yang dikerjakan seorang duta wisata pada masa baktinya. Tugas seorang duta wisata sangat beragam, dari mempromosikan kebudayaan baik di dalam atau luar negeri, menjadi tamu undangan pada acara-acara budaya atau sosial, hingga tugas mendampingi pejabat (walikota, gubernur, bahkan presiden). Oleh karena itu, diperlukan kualitas hubungan masyarakat yang tepat sasaran dalam sebuah organisasi untuk mampu membentuk citra Duta Wisata sebagai mediator promosi dan publikasi.

Demikian pula dengan strategi komunikasi yang merupakan paduan perencanaan komunikasi (communication planning) dengan manajemen komunikasi (communication management) untuk mencapai tujuan yang telah ditetapkan. Strategi komunikasi ini harus mampu menunjukan bagaimana operasionalnya secara praktis harus dilakukan, dalam arti bahwa pendekatan (approach) bisa berbeda sewaktu-waktu bergantung pada situasi dan kondisi. (Effendy, 2011:32). Strategi komunikasi harus didukung oleh teori, karena teori merupakan pengetahuan berdasarkan pengalaman (empiris) yang sudah diuji kebenarannya. Harold D. Laswell (dalam, Mulyana, 2010) memiliki teori yang relevan jika dikaitkan dengan strategi komunikasi. Laswell menyatakan, cara terbaik untuk menerangkan kegiatan komuniksi ialah menjawab pertanyaan "Who Says What Which Channel To Whom With What Effect?". Untuk mantapnya strategi komunikasi, maka segala sesuatunya harus dipertautkan dengan komponen yang merupakan jawaban terhadap pertanyaan dalam rumus Laswell tersebut. pertanyaan ini dipadukan dengan konsep McQuail (2011) dan Effendy (2011) dalam faktor yang penting untuk sebuah lembaga atau perusahaan yang termenejemen untuk menyusun strategi komunikasi.

Model SMCR Berlo digunakan dalam penelitian memiliki komponen-komponen komunikasi diantaranya Source/S (sumber informasi), Message/M (pesan-pesan atau berbagai informasi yang disampaikan), Channel/C (media penyampaian pesan) dan Receiver/R (sasaran). Komponen pertama dan terakhir ini keduanya sama-sama dipengaruhi oleh empat faktor, yaitu communication skills, knowledge, attitude dan social cultural system. Penelitian ini bertujuan untuk mengetahui bagaimana strategi komunikasi Dinas Kebudayaan Dan Pariwisata Provinsi Jawa Timur dalam mendayagunakan 
Raka Raki Jawa Timur. Tujuan tersebut dapat dicapai dengan adanya pemaparan menyeluruh bagaimana Dinas Kebudayaan Dan Pariwisata Provinsi Jawa Timur sebagai otoritas penyelenggara Raka Raki Jawa Timur menyampaikan pesan melalui saluran komunikasi yang tepat kepada audiennya (masyarakat). Pesan tersebut disampaikan oleh Dinas Kebudayaan Dan Pariwisata Provinsi Jawa Timur berangkat dari sebuah tim yang memiliki karakteristik berupa brand identity. Adapun pesan itu sendiri adalah nilai brand kepariwisataan yang kemudian disampaikan melalui elemen-elemen brand (Raka Raki Jawa Timur). Lalu pesan berusaha ditangkap oleh audien dengan bukti adanya brand image dalam benak masyarakat.

Strategi komunikasi terfokus pada pendekatan Wilson dan Ogden (2015:205) dalam Strategic Communications yang dibagi dalam 3 (tiga) tahapan yaitu, perumusan strategi, implementasi strategi dan evaluasi strategi. Perumusan strategi adalah tahap awal pada manajemen strategi, yang mencakup mengembangkan visi dan misi, mengidentifikasi peluang eksternal organisasi dan ancaman, menentukan kekuatan dan kelemahan internal, menetapkan tujuan jangka panjang, menghasilkan strategi alternatif dan memilih strategi tertentu untuk mencapai tujuan. Implementasi strategi adalah tahap selanjutnya sesudah perumusan strategi yang ditetapkan. Penerapan strategi ini memerlukan suatu keputusan dari pihak yang berwenang dalam mengambil keputusan untuk menetapkan tujuan tahunan, menyusun kebijakan, memotivasi dan mengalokasikan sumber daya sehingga strategi yang dirumuskan dapat dilaksanakan. Pada tahap ini dilakukan pengembangan strategi pendukung budaya, merencanakan struktur organisasi yang efektif, mengatur ulang usaha pemasaran yang dilakukan, mempersiapkan budget (anggaran), mengembangkan dan utilisasi sistem informasi serta menghubungkan kinerja organisasi. Evaluasi strategi adalah tahap akhir dalam manajemen strategis. Konseptor sangat membutuhkan untuk tahu kapan strategi tertentu tidak bekerja dengan baik. Evaluasi strategi adalah alat utama untuk memperoleh informasi ini. Hal tersebut dapat dilakukan dengan penilaian atau melakukan proses evaluasi strategi.

Penelitian ini dilatarbelakangi keinginan untuk mengetahui strategi komunikasi Dinas Kebudayaan Dan Pariwisata Provinsi Jawa Timur dalam mendayagunakan Raka Raki Jawa Timur. Analisis strategi komunikasi dilakukan untuk mengetahui apakah manajemen dan komunikasi yang berjalan dan diterapkan telah sesuai (optimal) yang ditunjang dari teori SMCR Berlo (1960) guna mengidentifikasi komponen-komponen komunikasi sesuai dengan penelitian ini dalam mempengaruhi dalam strategi komunikasi tersebut seperti ada kekeliruan sarana atau sumberdaya.

Berdasarkan pemaparan latar belakang tersebut, maka masalah penelitian ini adalah "Bagaimanakah strategi komunikasi Dinas Kebudayaan dan Pariwisata Provinsi Jawa Timur dalam mendayagunakan Raka Raki Jawa Timur?”.

\section{B. METODE PENELITIAN}

Penelitian ini menggunakan pendekatan kualitatif, sementara tipe pendekatan penelitian bersifat deskriptif. Hal ini juga dimaksudkan untuk memberikan gambaran tentang suatu keadaan secara objektif melalui serangkaian langkah-langkah pengumpulan data, klasifikasi data, pengolahan serta analisis data (Prasetyo dan Jannah, 2008:11). Penelitian ini dilakukan untuk memberikan gambaran lebih detail tentang strategi komunikasi Dinas Kebudayaan dan Pariwisata Provinsi Jawa Timur dalam mendayagunakan Raka Raki Jawa Timur. Teknik pengumpulan data yang digunakan oleh peneliti di dalam penelitian ini adalah dengan menggunakan studi lapangan (wawancara). Wawancara ini dilakukan berdasarkan pedoman wawancara yang dibuat oleh penulis kepada informan yang terlibat, baik secara langsung maupun tidak langsung, baik dalam situasi formal maupun informal (Bungin, 2008:24). Informan dipilih berdasar kriteria-kriteria : menyesuikan waktu dengan kegiatan informan d alam kegiatan penelitian ini, sehingga peneliti dan informan dapat selalu bekerja sama; terlibat langsung dalam 
penelitian ini sebagai pihak berwenang dalam hal pihak penyelenggara Pemilihan Duta Wisata Raka Raki; serta produktif dalam berdiskusi, sehingga menghasilkan 2 (dua) komunikasi arah guna mengetahui pokok permasalahan dalam topik yang dibahas dengan informan kunci. Analisis data dilakukan dengan mengorganisasikan secara kualitatif dengan keabsahan data berupa teknik triangulasi.

Teknik analisis data terbagi dalam 3 (tiga) alur aktivitas yaitu (Moleong, 2013):

1. Reduksi data

Tahap awal dalam analisis data pada penilitian ini adalah reduksi data yang merangkum, memilih hal-hal yang pokok, memfokuskan pada hal-hal yang penting, dicari tema dan polanya. Data yang direduksi akan memberikan gambaran yang lebih jelas, dan mempermudah peneliti untuk melakukan pengumpulan data selanjutnya, dan mencarinya bila diperlukan. Tahap ini, peneliti mencari dan mengumpulkan jurnal, peraturan-peraturan terkait, dan dokumen tertulis dari Dinas Kebudayaan dan Pariwisata Provinsi Jawa Timur ataupun lansiran dari berita nasional terkait topik penelitian. Setelah itu, dilakukan pengumpulan data melalui wawancara mendalam kepada informan yang terlibat dan diubah ke dalam bentuk tertulis.

2. Penyajian data (data display)

Setelah melakukan reduksi data, langkah berikut adalah penyajian data yang dilakukan dalam bentuk uraian, bagan, hubungan kategori, flowchart dan sejenisnya. Penyajian data dilakukan melalui teks naratif yang bersifat deskriptif dan dibantu dengan beberapa gambar dan tabel yang sesuai dengan permasalahan yang diangkat oleh peneliti, yaitu strategi komunikasi Dinas Kebudayaan dan Pariwisata Provinsi Jawa Timur dalam mendayagunakan Raka Raki Jawa Timur. Tujuan penggunaan gambar dan tabel yang sesuai juga adalah untuk memudahkan dalam penyampaian pesan.

3. Kesimpulan dan/atau verifikasi

Langkah terakhir pada aktivitas dalam analisis data ini adalah menarik atau membuat kesimpulan. Setelah melakukan penyajian data, peneliti membuat kesimpulan berdasarkan dari hasil penelitian yang ada.

Triangulasi diperoleh dengan cara melakukan pengecekan terhadap informasi yang diperoleh berdasarkan informan yang berasal dari Dinas Kebudayaan dan Pariwisata Provinsi Jawa Timur. Informasi yang diperoleh dari hasil wawancara mendalam juga didukung dengan data yang didapatkan dari website Dinas Kebudayaan dan Pariwisata Provinsi Jawa Timur, berita nasional, artikel yang terkait dengan penelitian ini, serta dokumen tertulis.

\section{HASIL DAN ANALISIS}

\section{Gambaran Umum Objek Penelitian}

\section{Profil Dinas Kebudayaan dan Pariwisata Provinsi Jawa Timur}

Disbudpar Jatim sebagaimana mempunyai tugas membantu Gubernur melaksanakan urusan pemerintahan dibidang kebudayaan dan dibidang pariwisata yang menjadi kewenangan daerah dan tugas pembantuan yang diberikan kepada Provinsi Jawa Timur sebagaimana termaktub dalam RPJMD (Rencana Pembangunan Jangka Menengah Daerah) Provinsi Jatim Tahun 2014 - 2019. Adapun Disbudpar Jatim beralamat di Jalan Wisata Menanggal Nomor 1 Surabaya dengan akses alamat website http:/www.disbudpar.jatimprov.go.id.

Visi :

"Terwujudnya masyarakat yang sejahtera dan berkarakter dengan mengembangkan kepariwisataan dan kebudayaan"

70 Jurnal Kepariwisataan: Destinasi, Hospitalitas dan Perjalanan, Volume 3 Nomor 2, 2019: 67-78 
Misi :

Mengembangkan kepariwisataan yang berdaya saing, berkelanjutan serta promosi pariwisata yang berkualitas;

Meningkatkan apresiasi dan pemahaman masyarakat terhadap nilai dan keragaman budaya, serta pelestarian warisan budaya.

Tujuan :

Meningkatkan kontribusi sektor pariwisata melalui pengembangan pemasaran dan destinasi pariwisata;

a) Meningkatkan kualitas dan kuantitas pelaku seni dalam penciptaan kreatifitas dan karya seni sesuai dengan nilai nilai budaya;

b) Meningkatkan kualitas perlindungan, pengembangan, dan pemanfaatan warisan budaya. Sasaran :

Berdasar pada tujuan pembangunan yang telah ditetapkan, maka sasaran pembangunan Disbudpar Jatim adalah sebagai berikut:

a) Meningkatnya kunjungan, devisa dan pengeluaran wisatawan di Jawa Timur;

b) Meningkatnya konstribusi pariwisata terhadap PDRB Jawa Timur;

c) Meningkatnya kuantitas dan kualitas SDM Pariwisata.

\section{Struktur Organisasi}

Sebagaimana kajian bahasan dalam mendayagunakan Raka Raki Jawa Timur terfokus pada tugas dan fungsi masing-masing Bidang dan Unit Pelaksana Teknis (UPT), khususnya Bidang Industri Pariwisata.

Bidang Industri Pariwisata sebagaimana dimaksud dalam Pasal 3 ayat (1) huruf f Peraturan Gubernur Jawa Timur Nomor 65 tahun 2016, mempunyai tugas melaksanakan perumusan dan pelaksanaan kebijakan pengembangan, serta pemberian bimbingan teknis dan evaluasi industri pariwisata di bidang kemitraan usaha pariwisata, standar usaha pariwisata dan sertifikasi kompetensi di bidang pariwisata; (2) untuk melaksanakan tugas sebagaimana dimaksud pada ayat (1), bidang industri pariwisata, mempunyai fungsi:

a) Perumusan kebijakan pengembangan di bidang industri pariwisata;

b) Pelaksanaan kerjasama dengan lintas sektor dan pemerintah kabupaten/kota serta stakeholder di bidang industri pariwisata;

c) Pelaksanaan kebijakan teknis pengembangan di bidang industri pariwisata;

d) Pengoordinasian kebijakan pengembangan di bidang industri pariwisata;

e) Pelaksanaan bimbingan teknis di bidang industri pariwisata; dan

f) Pelaksanaan monitoring, evaluasi dan pelaporan di bidang industri pariwisata.

\section{Raka Raki Jawa Timur}

Raka Raki Jawa Timur adalah dipilih atau ditunjuk secara langsung atau diseleksi terlebih dahulu melalui proses pemilihan dengan berbagai tahapan seleksi. Dalam hal ini duta wisata diharapkan dapat bekerjasama dengan Pemerintah yakni Dinas Kebudayaan dan Pariwisata Jawa Timur serta menjadi ikon daerah Jawa Timur yang mampu menjadi pembicara serta membagikan informasi tentang potensi pariwisata Jawa Timur kepada masyarakat luas sehingga masyarakat luas tertarik untuk mengunjungi Jawa Timur sebagai destinasi kegiatan pariwisata. Raka Raki Jawa Timur disyaratkan berpenampilan yang simpatik, yang kemudian diarahkan untuk dapat menggapai visi terwujudnya duta wisata sebagai generasi yang berkualitas, santun, berdedikasi untuk melestarikan budayanya. 
Raka Raki Jawa Timur memiliki peran besar dalam menjalankan tugasnya sebagai Brand Ambassador di Dinas Kebudayaan dan Pariwisata Jawa Timur. Perannya sebagai komunikan untuk ikut andil dalam memperkenalkan pariwisata di Jawa Timur untuk melestarikan serta mempromosikan pariwisata terlihat dari tanggung jawab yang dijalankan oleh duta wisata disetiap tugas yang diberikan oleh sesuai dengan bidang yang membutuhkan. Selain itu kerjasama dengan para stakeholder membuat duta wisata dapat semakin mengeksplor tidak hanya kebudayaan dan pariwisata melainkan semua aspek yang menjadi daya tarik di Jawa Timur. Hal ini menunjukan adanya perubahan sikap dan tindakan konsumen yang menjadi tujuan utama Dinas Pariwisata mengajak duta wisata sebagai partner dalam kegiatan pemasaran dan promosi yang tentunya memberikan citra positif pada kemajuan kebudayaan dan pariwisata di Jawa Timur.

Peran Raka Raki Jawa Timur dalam mempromosikan pariwisata di Jawa Timur dilihat dari duta wisata sebagai promotor dalam hal ini duta wisata dianggap sebagai pihak terbaik sebagai promotor kepariwisataan sebayanya karena mereka adalah pemuda pemudi yang konsen terhadap perkembangan pariwisata. Melalui mereka para wisatawan mendapatkan informasi yang tentunya akan membangun citra positif atau negatif, semua kembali terhadap informasi yang diberikan dan bagaimana duta wisata tersebut menyampaikan informasi yang mereka ketahui. Kini duta wisata menjadi pilihan utama dalam melakukan sosialisasi untuk menjadikan citra positif bahwa pengembangan kepariwisataan sudah dapat dilepas dan ditugaskan kepada para pemuda pemudi daerah.

\section{Temuan Strategi Komunikasi}

Informan penelitian ini sebagai berikut:

a) Suriaman, SH, MSi (Pembina TK. I Bidang Industri Pariwisata Disbudpar Jatim)

b) Briansyah Dewandri Septiawan S.Hum (Ketua Harian Ikatan Raka Raki Jatim/ IRARI)

c) Kevin Dwijaya Pamungkas Sebo, S.E. (Raka Raki/Kepala Divisi Keuangan).

Pertanyaan didasarkan pada indikator strategi komunikasi terfokus pada pendekatan Wilson dan Ogden (2015:205) dalam Strategic Communications yang dibagi dalam 3 (tiga) tahapan yaitu, perumusan strategi, implementasi strategi dan evaluasi strategi secara menyeluruh.

\section{a. Perumusan Strategi}

Berdasarkan hasil wawancara peneliti dengan informan kunci dan pendukung (tabel 1) terkait perumusan strategi komunikasi Disbudpar Jatim dalam mendayagunakan Raka Raki Jawa Timur adalah didasarkan pada visi dan misi, identifikasi peluang eksternal organisasi dan ancaman, kekuatan dan kelemahan internal, tujuan jangka panjang Raka Raki Jawa Timur dan strategi alternatif dalam mendayagunakan Raka Raki Jawa Timur.

Tabel 1 Transkrip Wawancara mengenai Perumusan Strategi

\begin{tabular}{|c|c|c|c|c|}
\hline \multirow[b]{2}{*}{ No } & \multirow[b]{2}{*}{ Indikator } & \multicolumn{3}{|c|}{ Informan } \\
\hline & & $\begin{array}{c}\text { Pembina TK.1 Disbudpar } \\
\text { Jatim }\end{array}$ & Ketua Harian IRARI & IRARI (Anggota) \\
\hline 1. & $\begin{array}{l}\text { Visi misi dan } \\
\text { identifikasi } \\
\text { peluang } \\
\text { eksternal dan } \\
\text { kekuatan }\end{array}$ & $\begin{array}{l}\text { Visi misi ini juga didukung } \\
\text { peluang yang dilakukan } \\
\text { Disbudpar Jatim, yakni } \\
\text { adanya muda mudi } \\
\text { bertalenta di } 38 \\
\text { Kabupaten/Kota yang ada }\end{array}$ & $\begin{array}{l}\text { Sumbangsih tenaga } \\
\text { dan pikiran, karena } \\
\text { IRARI merupakan } \\
\text { menyempatkan } \\
\text { waktu menjadi } \\
\text { penggerak dalam }\end{array}$ & $\begin{array}{l}\text { Dukungan visi misi } \\
\text { ini juga didukung } \\
\text { dari sisi peluang } \\
\text { dan kekuatan } \\
\text { terselenggaranya } \\
\text { kegiatan/program } \\
\text { Raka Raki Jawa }\end{array}$ \\
\hline
\end{tabular}

72 | Jurnal Kepariwisataan: Destinasi, Hospitalitas dan Perjalanan, Volume 3 Nomor 2, 2019: 67-78 


\begin{tabular}{|c|c|c|c|c|}
\hline \multirow[b]{2}{*}{ No } & \multirow[b]{2}{*}{ Indikator } & \multicolumn{3}{|c|}{ Informan } \\
\hline & & $\begin{array}{l}\text { Pembina TK.1 Disbudpar } \\
\text { Jatim }\end{array}$ & Ketua Harian IRARI & IRARI (Anggota) \\
\hline & & $\begin{array}{l}\text { di Jawa Timur untuk eksis } \\
\text { dalam berprestasi }\end{array}$ & $\begin{array}{l}\text { pemilihan Raka Raki } \\
\text { jatim tiap tahun. }\end{array}$ & $\begin{array}{l}\text { Timur. Peluang } \\
\text { IRARI }\end{array}$ \\
\hline 2. & $\begin{array}{l}\text { Kelemahan } \\
\text { internal } \\
\text { organisasi dan } \\
\text { ancaman }\end{array}$ & $\begin{array}{l}\text { Kendala jarak, usia, dan } \\
\text { pendidikan dalam } \\
\text { mengikuti program } \\
\text { pemberdayaan yang } \\
\text { berpusat di Kota } \\
\text { Surabaya. Stigma } \\
\text { masyarakat terhadap } \\
\text { peran Raka Raki Jawa } \\
\text { Timur }\end{array}$ & $\begin{array}{l}\text { Belum sepenuhnya } \\
\text { meluangkan waktu } \\
\text { (manajemen waktu) } \\
\text { kegiatan/program } \\
\text { program Raka Raki } \\
\text { Jawa Timur }\end{array}$ & $\begin{array}{l}\text { Stigma masyarakat } \\
\text { terhadap peran } \\
\text { Raka Raki Jawa } \\
\text { Timur sebagai } \\
\text { penerima tamu, } \\
\text { bukan sebagai } \\
\text { promotor } \\
\text { pariwisata di Jawa } \\
\text { Timur }\end{array}$ \\
\hline 3. & $\begin{array}{l}\text { Strategi } \\
\text { alternatif } \\
\text { sebagai tujuan } \\
\text { jangka } \\
\text { panjang Raka } \\
\text { Raki Jawa } \\
\text { Timur }\end{array}$ & $\begin{array}{l}\text { Mengoptimalkan } \\
\text { eksistensi Raka Raki Jatim } \\
\text { dibidang kepemudaan } \\
\text { dan kepariwisataan } \\
\text { melalui organisasi yang } \\
\text { berbadan hukum yaitu } \\
\text { IRARI }\end{array}$ & $\begin{array}{l}\text { Kesuksesan IRARI } \\
\text { dalam mendukung } \\
\text { pendayagunaan Raka } \\
\text { Raki Jawa Timur }\end{array}$ & $\begin{array}{l}\text { Raka Raki Jawa } \\
\text { Timur dapat } \\
\text { dijadikan rujukan } \\
\text { terhadapat } \\
\text { organisasi- } \\
\text { organisasi lain yang } \\
\text { masih berada pada } \\
\text { level daerah }\end{array}$ \\
\hline
\end{tabular}

b. Implementasi strategi

Sebagaimana hasil wawancara peneliti dengan informan kunci dan pendukung (tabel 2) terkait implementasi strategi komunikasi Disbudpar Jatim dalam mendayagunakan Raka Raki Jawa Timur adalah didasarkan pada pendukung budaya dan struktur organisasi, pemasaran yang dilakukan dan budget (anggaran) sebagai utilisasi kinerja organisasi dalam mendayagunakan Raka Raki Jawa Timur.

Tabel 2 Transkrip Wawancara Mengenai Impelentasi Strategi

\begin{tabular}{|c|c|c|c|c|}
\hline \multirow[b]{2}{*}{ No } & \multirow[b]{2}{*}{ Indikator } & \multicolumn{3}{|c|}{ Informan } \\
\hline & & $\begin{array}{c}\text { Pembina TK.1 } \\
\text { Disbudpar Jatim }\end{array}$ & Ketuha Harian IRARI & IRARI (Anggota) \\
\hline 1. & $\begin{array}{l}\text { Pendukung } \\
\text { budaya dan } \\
\text { struktur } \\
\text { organisasi }\end{array}$ & $\begin{array}{l}\text { IRARI Jatim sebagai } \\
\text { mitra kerja (organisasi } \\
\text { non profit) dalam } \\
\text { mendukung } \\
\text { mempromosikan } \\
\text { keanekaragaman } \\
\text { budaya dan pariwisata } \\
\text { Jawa Timur }\end{array}$ & $\begin{array}{l}\text { IRARI Jatim sebagai } \\
\text { mitra kerja (organisasi } \\
\text { non profit) dalam } \\
\text { mendukung } \\
\text { mempromosikan } \\
\text { keanekaragaman } \\
\text { budaya dan pariwisata } \\
\text { Jawa Timur }\end{array}$ & $\begin{array}{l}\text { IRARI sebagai } \\
\text { struktur } \\
\text { organisasi Raka } \\
\text { Raki Jawa Timur } \\
\text { dibuat berbadan } \\
\text { hukum melalui } \\
\text { akte pendirian } \\
\text { notaris dan } \\
\text { terdaftar di } \\
\text { Kemenkumham. }\end{array}$ \\
\hline
\end{tabular}




\begin{tabular}{|c|c|c|c|c|}
\hline \multirow[b]{2}{*}{ No } & \multirow[b]{2}{*}{ Indikator } & \multicolumn{3}{|c|}{ Informan } \\
\hline & & $\begin{array}{c}\text { Pembina TK.1 } \\
\text { Disbudpar Jatim }\end{array}$ & Ketuha Harian IRARI & IRARI (Anggota) \\
\hline 2. & $\begin{array}{l}\text { Pemasaran } \\
\text { yang } \\
\text { dilakukan dan } \\
\text { budget } \\
\text { (anggaran) }\end{array}$ & $\begin{array}{l}\text { Kerjasama sponsorship } \\
\text { kepada dinas/swasta } \\
\text { terkait dan stakeholder } \\
\text { di Jawa Timur atau } \\
\text { nasional, disamping } \\
\text { membangun media } \\
\text { secara online ataupun } \\
\text { offline. APBD sebagai } \\
\text { sumber anggaran. }\end{array}$ & $\begin{array}{l}\text { Kegiatan Raka Raki } \\
\text { Jatim dari rapat } \\
\text { triwulan, APBD } \\
\text { sebagai sumber } \\
\text { anggaran. }\end{array}$ & $\begin{array}{l}\text { program tahunan } \\
\text { yang } \\
\text { dilaksanakan, } \\
\text { APBD sebagai } \\
\text { sumber anggaran. }\end{array}$ \\
\hline
\end{tabular}

c. Evaluasi strategi

Evaluasi strategi komunikasi Disbudpar Jatim dalam mendayagunakan Raka Raki Jawa Timur adalah didasarkan peninjauan ulang faktor-faktor eksternal dan kinerja yang dilakukan, serta pengambilan langkah korektif dalam mendayagunakan Raka Raki Jawa Timur, seperti tergambar pada tabel 3.

Tabel 3 Evaluasi strategi

\begin{tabular}{|c|c|c|c|c|}
\hline \multirow[b]{2}{*}{ No } & \multirow[b]{2}{*}{ Indikator } & \multicolumn{3}{|c|}{ Informan } \\
\hline & & $\begin{array}{l}\text { Pembina TK.1 Disbudpar } \\
\text { Jatim }\end{array}$ & Ketuha Harian IRARI & IRARI (Anggota) \\
\hline 1. & $\begin{array}{l}\text { Peninjauan } \\
\text { ulang faktor- } \\
\text { faktor } \\
\text { eksternal dan } \\
\text { kinerja }\end{array}$ & $\begin{array}{l}\text { Rapat tidak terencana } \\
\text { atau tidak terjadwal, rapat } \\
\text { dilakukan } 3 \text { (tiga) bulan } \\
\text { sekali atau meyesuaikan }\end{array}$ & $\begin{array}{l}\text { Setiap triwulan } \\
\text { sekali dan dalam } \\
\text { kondisi force } \\
\text { majeure yang } \\
\text { membutuhkan } \\
\text { penanganan }\end{array}$ & $\begin{array}{l}\text { Rapat dilakukan } \\
\text { setiap triwulan } \\
\text { atau } 3 \text { bulan, } \\
\text { sehingga setiap } \\
\text { pejabat dan kepala } \\
\text { divisi di organisasi } \\
\text { Raka Raki Jatim }\end{array}$ \\
\hline 2. & $\begin{array}{l}\text { Langkah } \\
\text { korektif }\end{array}$ & $\begin{array}{l}\text { Program pelatihan SDM } \\
\text { Raka Raki Jatim }\end{array}$ & $\begin{array}{l}\text { Pemantauan } \\
\text { program kerja, } \\
\text { pengembangan } \\
\text { kualitas anggota } \\
\text { melalui pelatihan } \\
\text { dari divisi PSDM } \\
\text { melalui IRARI Camp }\end{array}$ & $\begin{array}{l}\text { Mengevaluasi } \\
\text { terkait proses } \\
\text { penyelenggaran } \\
\text { yang mungkin } \\
\text { dalam beberapa } \\
\text { waktu akan } \\
\text { mengalami } \\
\text { perubahan atau } \\
\text { pengembangan } \\
\text { sehingga dari } \\
\text { internal Raka Raki }\end{array}$ \\
\hline
\end{tabular}

74 Jurnal Kepariwisataan: Destinasi, Hospitalitas dan Perjalanan, Volume 3 Nomor 2, 2019: 67-78 


\section{Pembahasan Strategi Komunikasi}

Berdasarkan hasil pemaparan wawancara peneliti dengan informan dari Bidang Industri Pariwisata Disbudpar Jatim berikut perwakilan Ikatan Raka Raki Jatim dan Raka Raki Jatim (anggota) didapatkan informasi terkait apa saja yang berhubungan dengan problema strategi komunikasi Disbudpar Jatim dalam mendayagunakan Raka Raki Jawa Timur. Berdasarkan hasil analisis dari indikator strategi komunikasi terfokus pada pendekatan Wilson dan Ogden (2015:205) dalam Strategic Communications yang dibagi dalam 3 (tiga) tahapan yaitu, perumusan strategi, implementasi strategi dan evaluasi strategi secara menyeluruh. Berikut adalah hasil analisa peneliti berdasar strategi komunikasi Disbudpar Jawa Timur dalam mendayagunakan Raka Raki Jawa Timur.

Pertama, perumusan strategi komunikasi didasarkan pada visi dan misi, identifikasi peluang eksternal organisasi dan ancaman, kekuatan dan kelemahan internal, tujuan jangka panjang dalam mendayagunakan Raka Raki Jawa Timur. Diketahui perumusan strategi dinilai telah memenuhi visi dan misi, peluang dan kekuatan, serta memenuhi tujuan jangka panjang dalam mendukung terselenggaranya citra positif pengembangan kepariwisataan Jatim. Hal ini didasarkan fakta dilapangan, sebagai berikut:

a) Visi Raka-Raki Jawa Timur didayagunakan untuk mendukung mempromosikan keanekaragaman budaya dan pariwisata Jawa Timur

b) Misi pendayagunaan Raka-Raki Jawa Timur adalah untuk mengembangkan bakat, kemampuan dan kreativitas generasi muda berprestasi dibidang pariwisata.

c) Peluang yang dilakukan Disbudpar Jatim dalam pendayagunaan Raka-Raki Jawa, yakni adanya muda mudi bertalenta di 38 Kabupaten/Kota yang ada di Jawa Timur untuk eksis dalam berprestasi. Peluang ini menjadi kekuatan Disbudpar Jatim guna membantu mengoptimalisasi kunjungan wisata di 38 Kabupaten/Kota.

Guna mendukung perumusan strategi komunikasi yang dinilai telah memenuhi visi dan misi, peluang dan kekuatan terselenggaranya citra positif Raka Raki Jawa Timur, dibentuklan Ikatan Raka Raki (IRARI). IRARI berperan dalam sumbangsih tenaga dan pikiran, waktu menjadi penggerak dalam pemilihan Raka Raki jatim tiap tahun. Peluang IRARI adalah mendapat berbagai kemudahan dalam mendapatkan ilmu dan wawasan sosial antar anggota maupun dari eksternal organisasi.

Kendati demikian, terdapat ancaman dan kelemahan internal Disbudpar Jatim dalam menjalankan kegiatan/program Raka Raki Jawa Timur sejalan dengan visi misi dan peluang dan kekuatan yang dimiliki. Ancaman dan kelemahan diantaranya adalah

a) Keterbatasan dana dalam pemberdayaan Raka Raki setelah Grand Final Pemilihan Raka Raki Jawa Timur.

b) Kendala jarak, usia, dan pendidikan dalam mengikuti program pemberdayaan yang berpusat di Kota Surabaya.

c) Stigma masyarakat terhadap peran Raka Raki Jawa Timur sebagai penerima tamu, bukan sebagai promotor pariwisata di Jawa Timur.

Disamping, kelemahan internal Disbudpar Jatim dalam menjalankan kegiatan/program Raka Raki adalah belum sepenuhnya IRARI meluangkan waktu (manajemen waktu) kegiatan/program program Raka Raki Jawa Timur yang mempengaruhi aktivitas di luar kegiatan organisasi, seperti kuliah atau kerja. Guna mengatasi ancaman dan kelemahan internal Disbudpar Jatim dalam menjalankan visi misi dan peluang dan kekuatan yang dimiliki, maka Disbudpar Jatim melakukan strategi alternatif sebagai tujuan jangka panjang pendayagunaan Raka Raki Jawa Timur lebih optimal. Strategi dilakukan dengan mengoptimalkan eksistensi Raka Raki Jatim dibidang kepemudaan dan kepariwisataan melalui organisasi yang berbadan hukum yaitu IRARI dengan beragam program kerja baik yang didukung oleh Disbudpar Jatim maupun dana swadaya anggota IRARI. Tujuan strategi ini terealisasi dengan kegiatan pemberdayaan SDM Raka Raki Jatim ke luar provinsi Jawa Timur dan keluar negeri melalui pagelaran 
talenta-talenta Raka Raki Jatim yang dikemas dalam pagelaran wisata Jawa Timur. Sebagai contoh kesuksesan IRARI dalam mendukung pendayagunaan Raka Raki Jawa Timur adalah pelaksanaan Jambore Duta Wisata se-Indonesia, hal itu menjadi pembuktian atas keberhasilan organisasi ini dengan menggunakan anggaran non Disbudpar Jatim. Disamping Raka Raki Jawa Timur dapat dijadikan rujukan terhadapat organisasi-organisasi lain yang masih berada pada level daerah utamanya perihal kepariwisataan.

Kedua, implementasi strategi komunikasi didasarkan pada pendukung budaya dan struktur organisasi, pemasaran yang dilakukan dan budget (anggaran) sebagai utilisasi kinerja organisasi dalam mendayagunakan Raka Raki Jawa Timur. Implementasi strategi komunikasi Disbudpar Jatim telah disesuaikan dengan pendukung budaya dan struktur organisasi dibawah naungan Bidang Industri Pariwisata Disbudpar Jatim. Pendukung budaya dan struktur organisasi menjalankan kegiatan/program Raka Raki Jawa Timur didukung adanya IRARI Jatim sebagai mitra kerja (organisasi non profit) dalam mendukung mempromosikan keanekaragaman budaya dan pariwisata Jawa Timur. IRARI dalam sumbangsih menjalankan kegiatan/program Raka Raki Jawa Timur telah melakukan berkomitmen serta konsisten menjadi organisasi berbadan hukum yang pendirianya sudah mengikuti standar pendirian organisasi sesuai Undang-Undang dimulai tadi pendirian Akta Notaris dan sebagainya. IRARI menjadi organisasi perwakilan naungan Bidang Industri Pariwisata Disbudpar Jatim mendukung pemanfaatan Raka Raki Jawa timur oleh pihak swasta atau dinas terkait, baik Jawa Timur atau pemerintah Pusat melalui talenta talenta yang dimiliki. Seperti contohnya menjadi MC berbagai event swasta dan pemerintahan, model (fashion show) para UMKM skala regional sampai nasional, tim tari sebagai pembuka peresmian suatu acara, dan sebagainya.

Lebih lanjut, IRARI Jatim sebagai perwakilan naungan Bidang Industri Pariwisata Disbudpar Jatim menjadi medium pemasaran yang dilakukan Disbudpar Jatim. Pemasaran telah dilakukan dengan kerjasama sponsorship kepada dinas/swasta terkait dan stakeholder di Jawa Timur atau nasional, disamping membangun media secara online ataupun offline guna mendukung pengenalan Raka Raki Jatim, baik melalui koran pemerintah provinsi Jawa Timur, dan media online melalui website, Instagram, Facebook, YouTube dan Twitter. Guna mendukung kerjasama sponsorship maupun memanfaat berbagai media, anggaran kegiatan/program program Raka Raki Jawa Timur memanfaatkan APBD Pemerintah Provinsi Jawa Timur.

Ketiga, evaluasi strategi komunikasi didasarkan peninjauan ulang faktor-faktor eksternal dan kinerja yang dilakukan, serta pengambilan langkah korektif dalam mendayagunakan Raka Raki Jawa Timur.. Evaluasi strategi dalam Disbudpar Jatim dalam menjalankan kegiatan/program Raka Raki Jawa Timur didasarkan atas rapat tidak terencana atau tidak terjadwal, rapat dilakukan 3 (tiga) bulan sekali atau meyesuaikan dengan Kepala Bidang Industri Pariwisata Disbudpar Jatim dan IRARI. Adapun hasil dari evaluasi adalah

a) Raka Raki telah mengukir prestasi baik dilingkup provinsi dan juga nasional

b) Raka Raki Jawa Timur selalu menjadi kompetitor yang patut diperhitungkan oleh pesaing lain dalam sebuah ajang kompetensi

c) Usaha IRARI dalam menyiapkan delegasinya dalam sebelum berlaga, sehingga wakil dari Jawa Timur ini telah dibekali dengan hard skill dan soft skill, antara lain:

1. Mengadakan program pelatihan SDM Raka Raki Jatim terkait personality development, seperti pelatihan MC formal dan non formal, kewirausahaan, ngadi sliro ngadi busana pakem Raka Raki Jawa Timur, dan lain-lain

2. Mengadakan pelatihan pembuatan vlog berbasis kepariwisataan; serta mengarahkan IRARI untuk pelaksanaan audiensi dengan Gubernur Jawa Timur terkait program kerja IRARI. 
Selanjutnya, pada temuan analisis peneliti berdasar strategi komunikasi Disbudpar Jawa Timur dalam mendayagunakan Raka Raki Jawa Timur dilakukan identifikasi teori SMCR Berlo (1960) guna mengidentifikasi komponen-komponen komunikasi sesuai atau belum dengan penelitian ini dalam mempengaruhi dalam strategi komunikasi tersebut seperti ada kekeliruan sarana atau sumberdaya. Meliputi :

a. Source

Sumber komunikasi Disbudpar Jawa Timur dalam mendayagunakan Raka Raki Jawa Timur adalah dari Ikatan Raka Raki (IRARI). IRARI berperan dalam sumbangsih tenaga dan pikiran, waktu menjadi penggerak dalam pemilihan Raka Raki jatim tiap tahun. IRARI menjadi organisasi perwakilan naungan Bidang Industri Pariwisata Disbudpar Jatim mendukung pemanfaatan Raka Raki Jawa timur melalui talenta talenta yang dimiliki. Seperti contohnya menjadi MC berbagai event swasta dan pemerintahan, model (fashion show) para UMKM skala regional sampai nasional, tim tari sebagai pembuka peresmian suatu acara, dan sebagainya

b. Message

Adalah pengaturan suatu pesan dari awal, tengah, hingga akhir berupa kesimpulan atau sejenisnya. Pesan yang disampaikan Disbudpar Jawa Timur dalam mendayagunakan Raka Raki Jawa Timur telah sesuai, yakni memenuhi visi dan misi, peluang dan kekuatan, serta memenuhi tujuan jangka panjang; disesuaikan dengan pendukung budaya dan struktur organisasi dibawah naungan Bidang Industri Pariwisata Disbudpar Jatim; serta evaluasi strategi Disbudpar Jatim dalam menjalankan kegiatan/program Raka Raki Jawa Timur didasarkan atas rapat tidak terencana atau tidak terjadwal, rapat dilakukan 3 (tiga) bulan sekali atau meyesuaikan.

c. Channel

Merupakan saluran atau media yang dipilih untuk menyampaikan pesan komunikasi Disbudpar Jawa Timur dalam mendayagunakan Raka Raki Jawa Timur. Saluran atau media dibangun dengan konsep pemasaran, dimana Disbudpar Jawa Timur membangun media secara online ataupun offline guna mendukung pengenalan Raka Raki Jatim, baik melalui koran pemerintah provinsi Jawa Timur, dan media online melalui website, Instagram, Facebook, YouTube dan Twitter. Guna mendukung kerjasama sponsorship maupun memanfaat berbagai media, anggaran kegiatan/program program Raka Raki Jawa Timur memanfaatkan APBD Pemerintah Provinsi Jawa Timur.

Receiver

Sasaran Disbudpar Jawa Timur dalam mendayagunakan Raka Raki Jawa adalah calon Raka Raki ataupun anggota Raka Raki yang tergabung dalam IRARI. Sasaran Disbudpar Jawa Timur adalah menjadi kompetitor yang patut diperhitungkan oleh pesaing lain dalam sebuah ajang kompetensi, khususnya di 38 Kabupaten/Kota yang ada di Jawa Timur untuk eksis dalam berprestasi. Peluang ini menjadi kekuatan Disbudpar Jatim guna membantu mengoptimalisasi kunjungan wisata di 38 Kabupaten/Kota.

\section{SIMPULAN}

Berdasarkan hasil pemaparan wawancara peneliti dengan informan dari Bidang Industri Pariwisata Disbudpar Jatim berikut perwakilan Ikatan Raka Raki Jatim dan Raka Raki Jatim (anggota) didapatkan informasi terkait strategi komunikasi Disbudpar Jatim dalam mendayagunakan Raka Raki Jawa Timur. Berdasarkan hasil analisis dari indikator strategi komunikasi terfokus pada pendekatan strategic communications yang dibagi dalam 3 (tiga) tahapan yaitu, perumusan strategi, implementasi strategi dan evaluasi strategi secara menyeluruh. Berikut adalah hasil temuan peneliti berdasar strategi komunikasi Disbudpar Jawa Timur dalam mendayagunakan Raka Raki Jawa Timur.

Pertama, perumusan strategi komunikasi telah memenuhi visi dan misi, peluang dan kekuatan, serta memenuhi tujuan jangka panjang dalam mendukung terselenggaranya citra positif pengembangan 
kepariwisataan Jatim, yakni adanya muda mudi bertalenta di 38 Kabupaten/Kota yang ada di Jawa Timur untuk eksis dalam berprestasi. Kendati demikian, terdapat ancaman dan kelemahan internal, seperti keterbatasan dana, kendala jarak, usia, dan pendidikan dalam mengikuti program pemberdayaan yang berpusat di Kota Surabaya. Stigma masyarakat terhadap peran Raka Raki Jawa Timur sebagai penerima tamu, bukan sebagai promotor pariwisata di Jawa Timur. Strategi alternatif dilakukan dengan kegiatan pemberdayaan SDM Raka Raki Jatim ke luar provinsi Jawa Timur dan keluar negeri melalui IRARI.

Kedua, implementasi strategi komunikasi telah disesuaikan dengan pendukung budaya dan struktur organisasi dibawah naungan Bidang Industri Pariwisata Disbudpar Jatim. Pendukung budaya dan struktur organisasi menjalankan kegiatan/program Raka Raki Jawa Timur didukung adanya IRARI yang berbadan hukum. IRARI Jatim menjadi medium pemasaran yang dilakukan Disbudpar Jatim dalam membangun media secara online ataupun offline guna mendukung pengenalan Raka Raki Jatim dengan memanfaatkan APBD Pemerintah Provinsi Jawa Timur.

Ketiga, evaluasi strategi komunikasi dalam menjalankan kegiatan/program Raka Raki Jawa Timur didasarkan atas rapat tidak terencana atau tidak terjadwal, rapat dilakukan 3 (tiga) bulan sekali atau meyesuaikan dengan Kepala Bidang Industri Pariwisata Disbudpar Jatim dan IRARI. Adapun hasil dari evaluasi adalah Raka Raki telah mengukir prestasi dan menjadi kompetitor yang patut diperhitungkan ajang kompetensi yang telah dibekali dengan hard skill dan soft skill.

\section{DAFTAR REFERENSI}

Anggito, A., \& Setiawan, J. (2018). Metodologi penelitian kualitatif. Sukabumi: Jejak Publisher.

Ardial. (2018). Fungsi Komunikasi Organisasi: Studi Kasus Tentang Fungsi Komunikasi . Medan: Lembaga Penelitian dan Penulisan ilmiah AQLI.

Berlo, D. K. (1960). The Process of Communication: an Introduction to Theory and Practice. New York: Holt, Rinehart, and Winston .

Bungin, B. (2008). Penelitian Kualitatif: Komunikasi, Ekonomi, Kebijakan Publik, dan Ilmu Sosial Lainnya. Jakarta: Kencana.

Caropeboka, R. M. (2017). Konsep dan Aplikasi Ilmu Komunikasi. Yogyakarta: Andi Offset.

David, F. (2010). Manajemen Strategi Konsep. Jakarta: Salemba Empat.

Effendy, O. U. (2011). Ilmu Komunikasi. Teori dan Praktek. Bandung: Rosda.

Kriyantono, R. (2019). Pengantar Lengkap Ilmu Komunikasi Filsafat dan Etika Ilmunya Serta Perspektif Islam. Jakarta: Prenadamedia.

Liliweri, A. (2010). Strategi Komunikasi Masyarakat. Yogyakarta: LKIS Yogyakarta. . (2011). Dasar-Dasar komunikasi kesehatan. Yogyakarta: Pustaka Pelajar.

McQuail, D. (2011). Teori Komunikasi Massa McQuail 1, 6E . Jakarta: Salemba Humanika .

Moleong, L. J. (2013). Metode Penelitian Kualitatif (Edisi Revisi). Bandung: Remaja Rosdakarya.

Mulyana, D. (2010). Ilmu Komunikasi Suatu Pengantar, Cet. XIV. Bandung: Remaja Rosdakarya.

Nyoto. (2019). Buku Ajar Manajemen Sumber Daya Manusia. Ponorogo: Uwais

Inspirasi Indonesia.

Panuju, R. (2018). Pengantar Studi Ilmu Komunikasi. Jakarta: Kencana Prenada Mediagorup

Panuju, R. (2019). Komunikasi Pemasaran. Jakarta: Kencana Prenada Mediagroup.

Prasetyo, B., \& Jannah, L. M. (2008). Metode Penelitian Kuantitatif: Teori dan Aplikasi. Jakarta: Raja Grafindo Persada.

Sugiyono. (2008). Metode Penelitian Kualitatif dan R\&D. Bandung: Alfabeta.

Suprapto, T. (2009). Pengantar Teori \& Manajemen Komunikasi. Jakarta: Buku Kita.

Wilson, L. J., \& Ogden, J. D. (2015). Strategic Communications: Planning for Public Relations and Marketing. USA: Kendall/Hunt, 